\title{
La perduta Chiesa dell'Annunziata presso Porta san Giorgio a Palermo: ipotesi e ricostruzioni virtuali
}

\author{
Mirco Cannella
}

\section{Abstract}

La chiesa dell'Annunziata fu distrutta dai bombardamenti degli Alleati del 9 maggio 1943 sulla città di Palermo. Della chiesa, costruita sul finire del XVI e sita nei pressi della porta San Giorgio, rimangono tuttavia importanti testimonianze: un disegno del 1832 di Pierre-Joseph Garrez, conservato a Parigi, presso l'Ecole Nationale Supérieure des Beaux-Arts, i rilievi dell'architetto Nino Pollaci degli inizi del Novecento, una serie di foto storiche, i frammenti architettonici superstiti come i capitelli e il soffitto ligneo a cassettoni dipinto, conservati in vari musei palermitani, e soprattutto la torre campanaria, tuttora unica traccia in situ dell'ormai scomparsa chiesa dell'Annunziata.

A queste testimonianze si aggiunge un documento d'archivio del 1526 in cui viene stipulato un contratto per la costruzione di 14 piloni ottagonali compresi di base e capitelli che dovevano essere impiegati per il rinnovamento della chiesa secondo le indicazioni dell'architetto Antonio Belguardo. Da tale documento nasce la suggestiva ipotesi di un progetto che doveva stravolgere l'impianto originario della chiesa e che, per cause a noi ignote, non fu mai attuato. Lo studio proposto ha un duplice obiettivo: ricostruire la chiesa per riconfigurare virtualmente lo spazio urbano perduto attraverso l'elaborazione di alcune viste prospettiche e animazioni 3D, e riproporre un modello congetturale dell'ipotetico progetto proposto da Belguardo per il rinnovamento mai attuato della chiesa.

Parole chiave

ricostruzione virtuale, chiesa dell'Annunziata, Palermo, motion tracking, laser scanning.

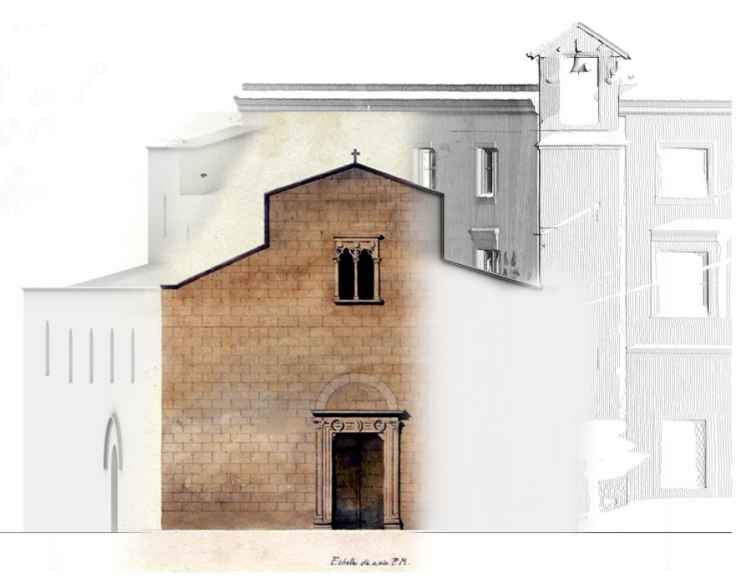

1842

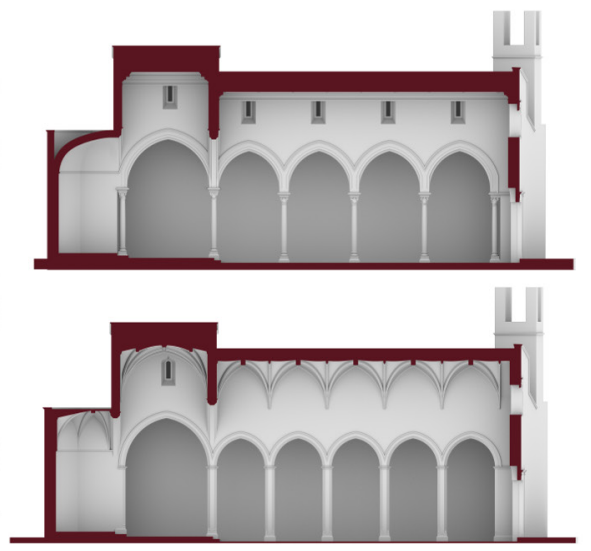

doi.org/ | 0.3280/oa-548. 10 


\section{La chiesa dell'Annunziata}

Durante l'ultimo conflitto mondiale la città di Palermo fu la prima in Italia a sperimentare gli effetti devastanti del bombardamento a tappeto da parte degli Alleati anglo-americani: dopo l'ultima incursione aerea, avvenuta nella notte del 9 maggio 1943, gran parte del tessuto urbano residenziale e monumentale della città era ormai ridotto a un cumulo di macerie. Tra gli edifici coinvolti nella devastazione rientra anche la chiesa dell'Annunziata che, centrata in pieno da un ordigno, fu completamente rasa al suolo. Nel sito in cui si ergeva un tempo la chiesa si trova oggi una piazza, denominata San Giorgio dei Genovesi, dal nome dalla chiesa cinquecentesca (tuttora esistente) edificata accanto all'Annunziata ma in posizione arretrata rispetto al fronte stradale (fig. I). A testimoniare l'esistenza della perduta chiesa rimangono il campanile, visibile sul lato destro della piazza, e il complesso edilizio un tempo ad essa annesso (in origine probabilmente un convento, divenuto nei secoli successivi orfanotrofio e oggi sede del Conservatorio di Musica di Palermo "A. Scarlatti"), (fig. 2).

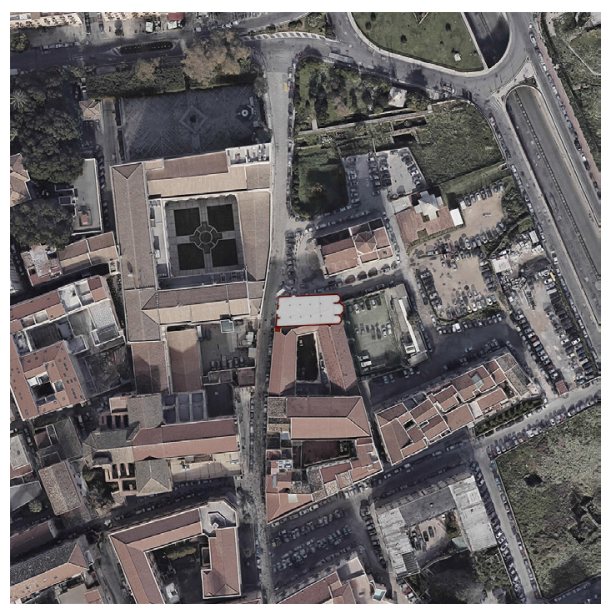

Non è facile avere un'idea chiara dell'impianto trecentesco della chiesa dell'Annunziata poiché, la mancanza di testimonianze antiche si associa al fatto che essa, sul finire del XV secolo, subì un importante intervento di restauro ad opera di Gabriele di Battista da Como, capomastro attivo in quegli anni a Palermo, che ne modificò profondamente l'aspetto [Nobile 2009, pp. 13-15]. Della struttura originaria venne probabilmente mantenuta la zona absidale di matrice poligonale [Garofalo 20 I5, p. 177], mentre, per separare le tre navate, furono inserite due file di cinque arcate colonnari con arco leggermente acuto. II restauro interessò anche gli esterni, con il rifacimento del prospetto principale nel quale, in particolare, vennero inseriti una bifora e un portale, realizzati in marmo bianco e riccamente scolpiti da Domenico Gagini. Allo stesso Gagini si devono inoltre le dodici colonne in marmo delle navate con rispettive basi e capitelli.

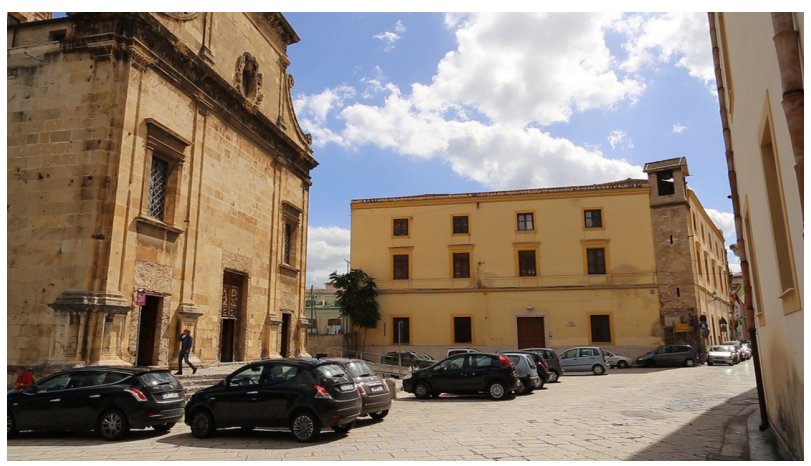




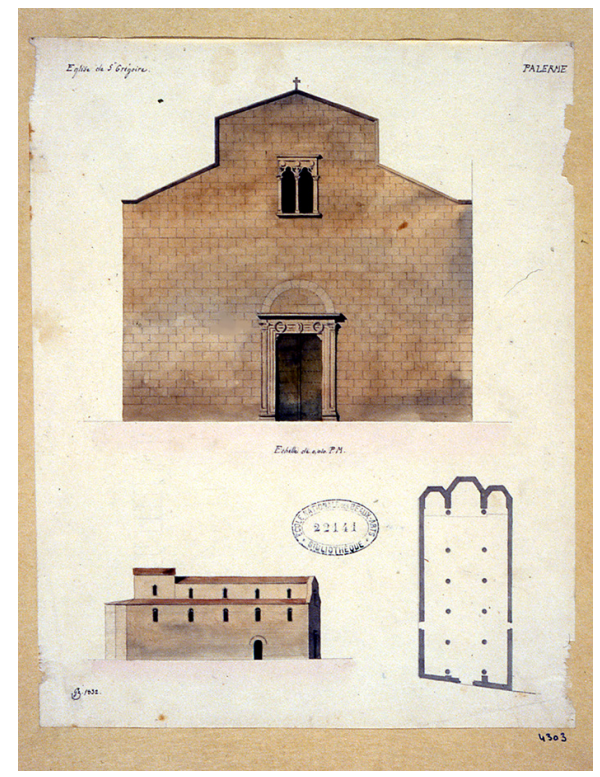

Questi ultimi, così come altri preziosi frammenti architettonici, sono in parte sopravvissuti grazie al loro recupero dalle macerie all'indomani del disastroso bombardamento, e sono oggi conservati presso la Galleria Regionale della Sicilia di palazzo Abatellis a Palermo. Al Museo Diocesano del Palazzo Arcivescovile di Palermo sono custodite invece le grandi tele che decoravano il soffitto a cassettoni della navata centrale, dipinte dall'artista campano Mario di Laurito (metà del XVI secolo).

La prima raffigurazione a noi giunta dell'ormai perduta chiesa consiste in una tavola acquerellata dell'architetto francese Pierre Joseph Garrez (I 802- | 852) (fig. 3). In quanto allievo dell'École des Beaux-Arts e vincitore del Gran Prix nel 1830, il Garrez aveva avuto la possibilità di trascorrere un periodo di formazione a Roma per dedicarsi allo studio dell'architet-

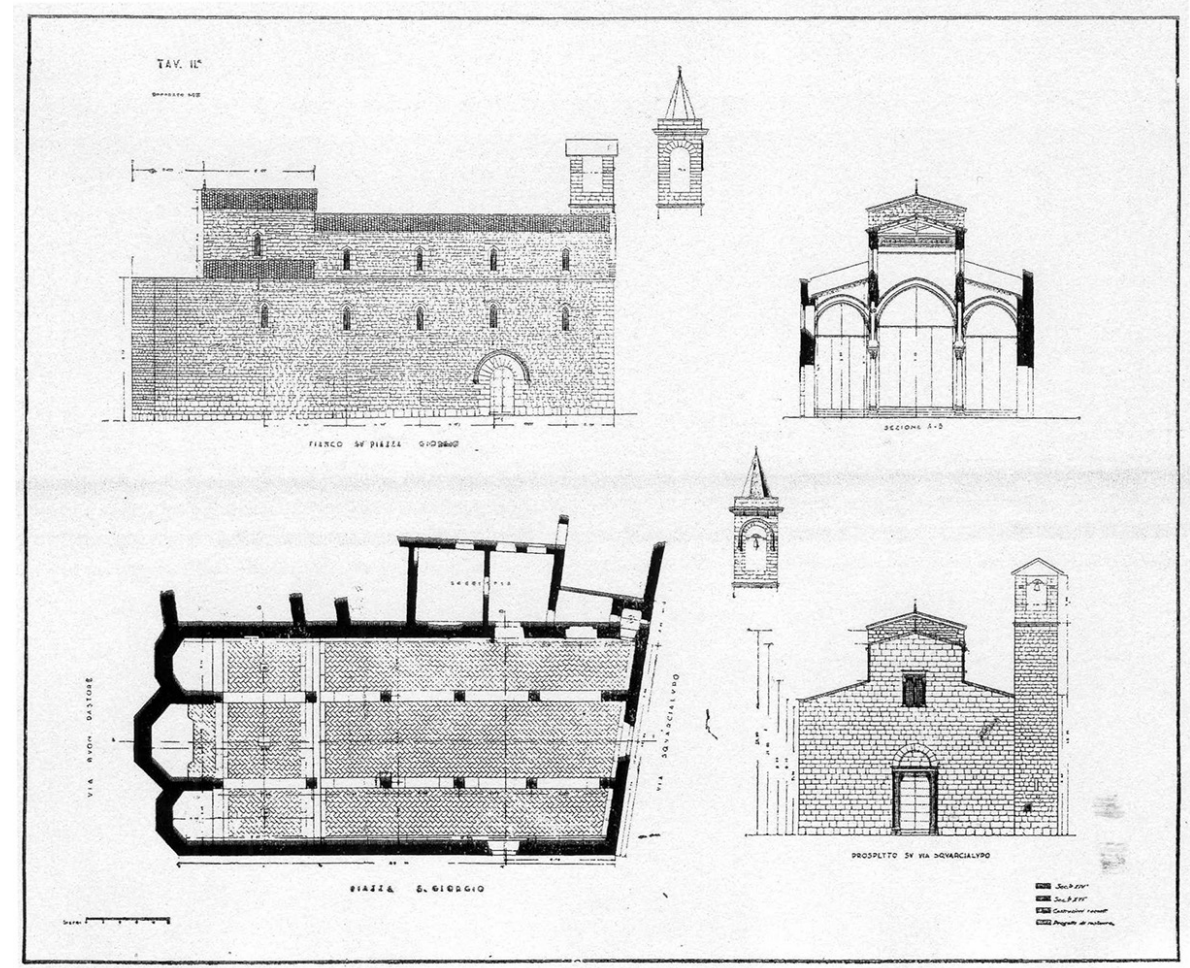


Fig. 5. Foto della prima metà del novecento del fronte principale della chiesa dell'Annunziata. tura classica e di intraprendere dei viaggi alla scoperta dell'Italia finalizzati all'analisi e al rilievo dell'architettura classica sulla base della conoscenza diretta di monumenti e siti archeologici. L'interesse dei giovani allievi di inizio Ottocento andava spesso oltre lo studio esclusivo dei siti classici: non è insolito infatti trovare tra i loro numerosi disegni anche accurati rilievi e minuziose rappresentazioni di edifici della tarda antichità e medievale [Savorra 2006, pp. 24-32]. L'itinerario del giovane architetto/artista francese coinvolse la Sicilia, dove Garrez giunse nel 1832: durante la sua permanenza egli eseguì i rilievi e realizzò su carta una tavola, a matita e acquerello, in cui rappresentava, a scale differenti, il prospetto principale, il fronte laterale sinistro e la pianta di una chiesa, da lui denominata erroneamente di San Gregorio. II disegno, oggi conservato all'École Nationale Supérieure des Beaux Arts a Parigi, riproduce in realtà la chiesa dell'Annunziata, come è stato osservato da M. R. Nobile [Nobile 2009, p. 14], e come confermato in base al confronto con alcune fotografie di inizio Novecento e alle corrispondenze con i rilievi realizzati, nello stesso periodo, dall'architetto Nino Pollaci.

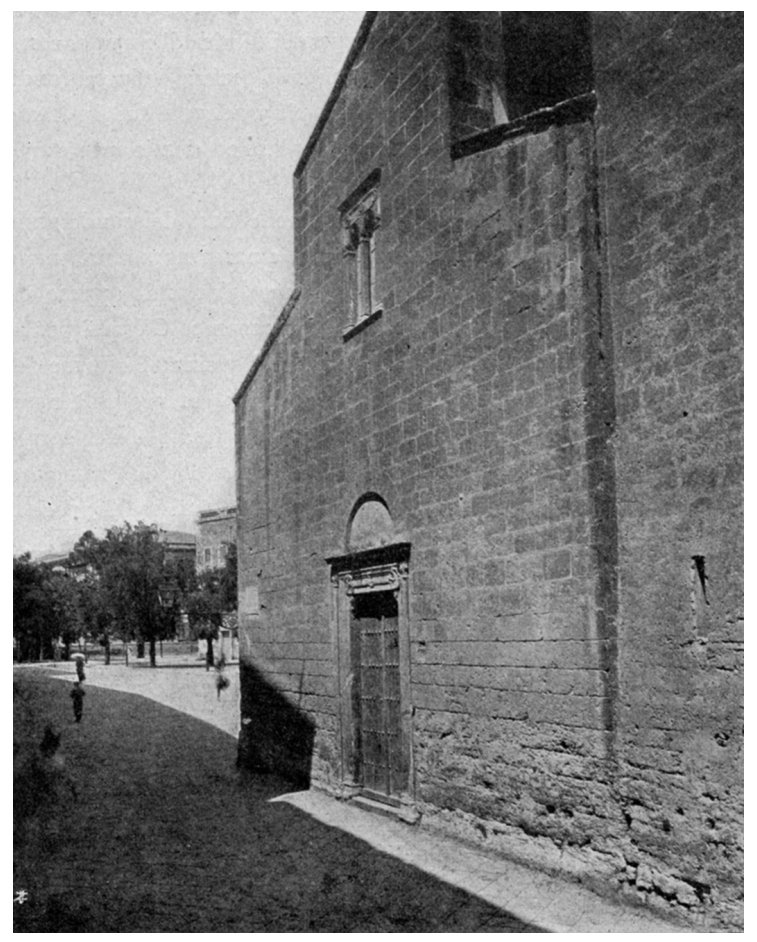

Attraverso il rilievo realizzato da Pollaci, pubblicato nel 1933 [Pollaci 1933] in dieci tavole, è possibile comprendere con chiarezza la struttura architettonica della chiesa (fig. 4). I disegni descrivono l'assetto complessivo dell'edificio attraverso una planimetria generale, una pianta, i prospetti, diverse sezioni e uno spaccato assonometrico. Altre tavole sono invece dedicate a particolari architettonici e decorativi come i capitelli, il portale e la bifora già citati e i profili al vero delle modanature degli archi delle navate nonché dei pulvini e delle basi delle colonne. Dai disegni si desume che la chiesa era lunga quasi 30 metri e larga 13,60, mentre la parte più alta del fronte principale non superava di poco i 12 metri; il campanile, mai ultimato, si interrompeva alla quota di 15,30 metri dal piano stradale (fig. 5).

II recente ritrovamento di un suggestivo documento d'archivio ha dato un nuovo impulso per l'avvio dello studio di questa architettura scomparsa: nel documento, del I 526 [Scaduto 2007, pp. 190-191], “i rettori della Chiesa dell'Annunziata a porta San Giorgio” conferiscono al magister Antonio Belguardo l'incarico di realizzare 14 pilastri a sezione ottagonale, larghi almeno 2 palmi siciliani [I] e un quarto e alti almeno |8, da utilizzare nella ristrutturazione della chiesa. Tale progetto non venne mai portato a termine ma alcuni dei suddetti pilastri, già realizzati, vennero comunque utilizzati in diverse parti dell'edificio annesso alla chiesa stessa, come è possibile evincere dai disegni dedicati a tale fabbrica realizzati dal Pollaci. 
Lo studio che viene qui proposto ha un duplice scopo: anzitutto si intende proporre una ricostruzione virtuale della chiesa dell'Annunziata nella configurazione antecedente alla sua distruzione e sostanzialmente nella versione cinquecentesca progettata da Gabriele da Como. Tale modello sarà impiegato per figurare lo scenario urbano originario in alcune prese fotografiche dello stato attuale attraverso tecniche di foto-inserimento, e la produzione di una animazione video attraverso l'utilizzo di tecniche di motion tracking.

Inoltre sarà presentata in questa sede l'ipotesi di una possibile configurazione del progetto mai realizzato, sulla base dell'analisi dei dati d'archivio e il confronto con alcune architetture realizzate dallo stesso Antonio Belguardo, impegnato, negli stessi anni, in altre importanti fabbriche della città di Palermo come la chiesa di Santa Maria della Catena e la più imponente chiesa di Santa Maria dello Spasimo.

Fig. 6. Rilievo

fotogrammetrico di uno dei capitelli realizzati da Domenico Gagini per la chiesa dell'Annunziata, oggi esposto nella sala della scultura della Galleria Regionale della Sicilia.
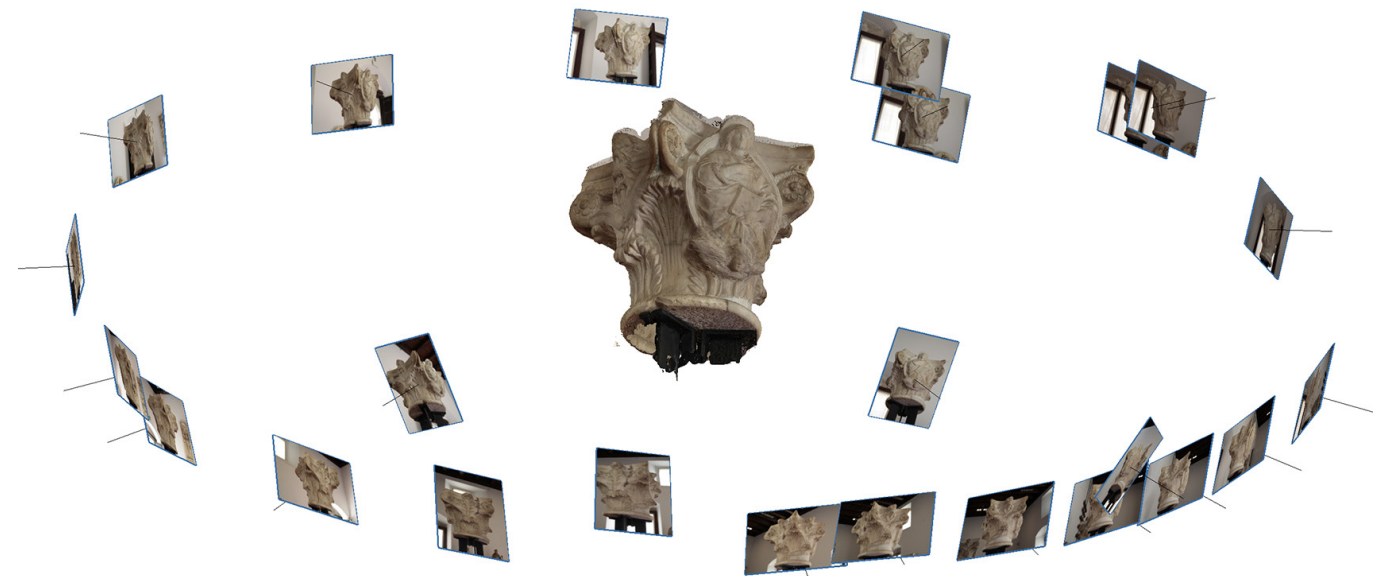

\section{Ricostruzione virtuale (progetto Gabriele da Como)}

La ricostruzione virtuale della chiesa dell'Annunziata ha preso le mosse dall'integrazione tra i dati metrici indicati dall'architetto Pollaci e le informazioni laser scanning.

Sono state realizzate una serie di acquisizioni con scanner laser per la documentazione dello stato di fatto e soprattutto della superstite torre campanaria, l'unico elemento utile alla verifica dimensionale dei rilievi novecenteschi e al corretto posizionamento virtuale della fabbrica nel tessuto edilizio. Contestualmente sono state effettuate delle prese fotografiche, finalizzate all'elaborazione di un progetto fotogrammetrico, e delle riprese video destinate alla produzione di animazioni con inserimento virtuale della fabbrica. Sono stati altresì rilevati i capitelli e le basi delle perdute colonne, esposti nella sala dedicata alla scultura del Museo di Palazzo Abatellis: ogni frammento è stato rilevato singolarmente con metodi fotogrammetrici al fine di ottenere delle copie digitali 3D da inserire nella ricostruzione virtuale della chiesa (fig. 6).

La ricostruzione digitale, elaborata in ambiente $C A D$, ha avuto inizio con la modellazione della torre campanaria sulla scorta dei dati laser scanning (fig. 7). L'integrazione dei dati con la ricca documentazione dei rilievi novecenteschi ha consentito una completa ricostruzione virtuale dell'intero edificio in tutti i suoi dettagli, nella sua configurazione antecedente alla sua distruzione nel secolo scorso. 
II modello, così realizzato, è stato impiegato per la produzione di alcune viste assonometriche e prospettiche (fig. 8). Successivamente esso è stato ulteriormente arricchito delle informazioni materiche, fondamentali per documentare l'intervento di riconfigurazione subito dalla chiesa rispetto al suo impianto originario trecentesco. Grazie alla lettura della dimensione dei conci effettuata attraverso i rilevi novecenteschi e soprattutto attraverso le foto storiche è stato possibile infatti individuare due differenti epoche di realizzazione: il fronte laterale e le absidi erano stati realizzati con l'utilizzo di conci di piccole dimensioni, in modo conforme alle tecniche costruttive tipiche del medioevo siciliano, mentre la facciata, così come il cantonale, vennero realizzati con blocchi di pietra arenaria di dimensioni maggiori, in linea con le tecniche in uso nel XV secolo e perfettamente compatibili con la già citata ristrutturazione.

Il trattamento superficiale del modello 3D è stato realizzato con texture elaborate tramite il campionamento di immagini fotografiche di paramenti murari di fabbriche coeve alle due differenti fasi costruttive. II modello, così testurizzato, è stato impiegato per simulare lo scenario urbano originale attraverso la realizzazione di alcuni fotomontaggi fotografici. La decisione di imporre un unico sistema di riferimento tra progetto fotogrammetrico e modello 3D ha permesso di recuperare tutti i parametri di posizione e direzione delle camere virtuali corrispondenti agli scatti selezionati.

La soluzione adottata ha facilitato il processo di sovrapposizione e fusione delle fotografie e delle viste renderizzate e di conseguenza l'editing dell'immagine finale. Un prodotto analogo ma applicato a una sequenza video è stato realizzato attraverso la tecnica del motion tracking, sfruttando gli strumenti disponibili nel software di modellazione 3D Blender (fig. 9). Questi consentono di calcolare il percorso effettuato dalla videocamera e di convertire tali spostamenti in una animazione nonché risolvere i parametri intrinseci della stessa come la lunghezza focale e le di distorsione dell'obiettivo. Tale processo avviene attraverso procedure semi automatiche di analisi e individuazione di punti omologhi su ogni singolo fotogramma e il successivo calcolo della posizione nello spazio degli stessi. L'ulteriore introduzione nel processo di calcolo di punti noti rintracciati sui fotogrammi in modo manuale, come nel caso in esame, permette di facilitare i successivi passaggi di scalatura e di definizione di un sistema di riferimento comune tra l'animazione della camera e i modelli 3D realizzati.

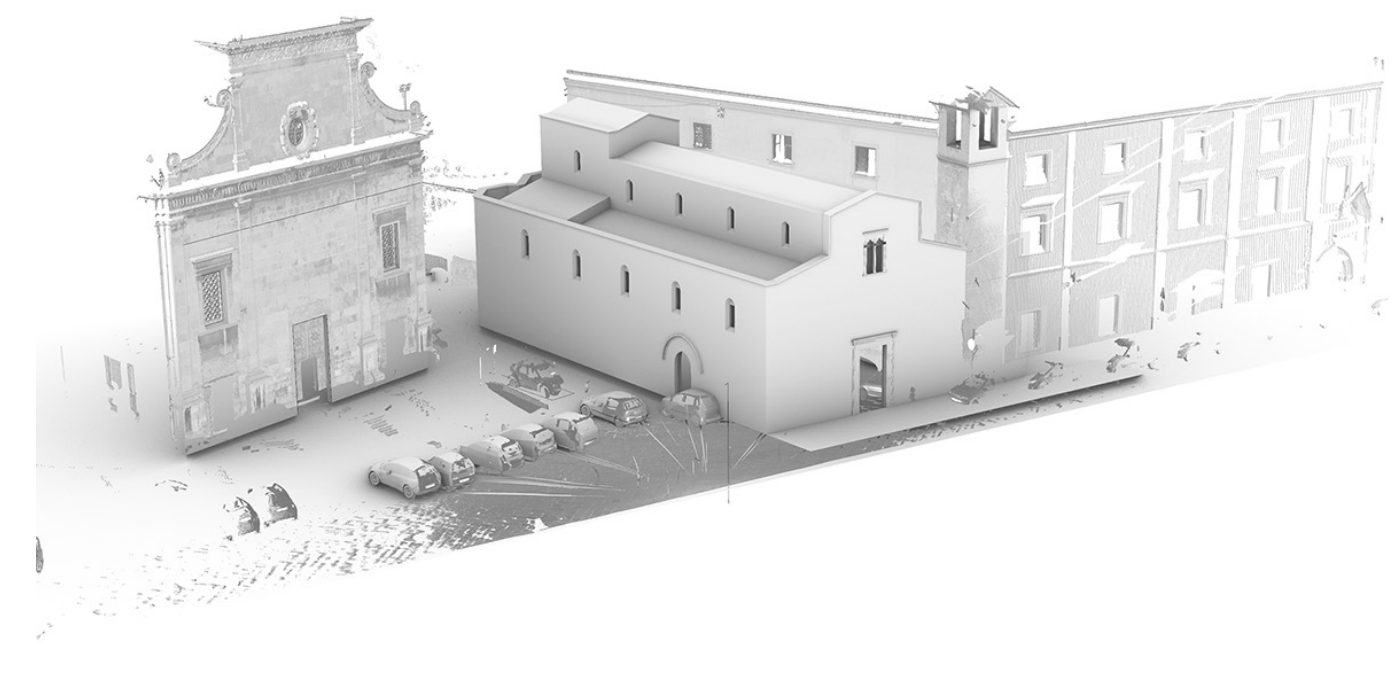


Fig. 8. Spaccato prospettico del modello virtuale della chiesa dell'Annunziata così come si presentava nel 1943

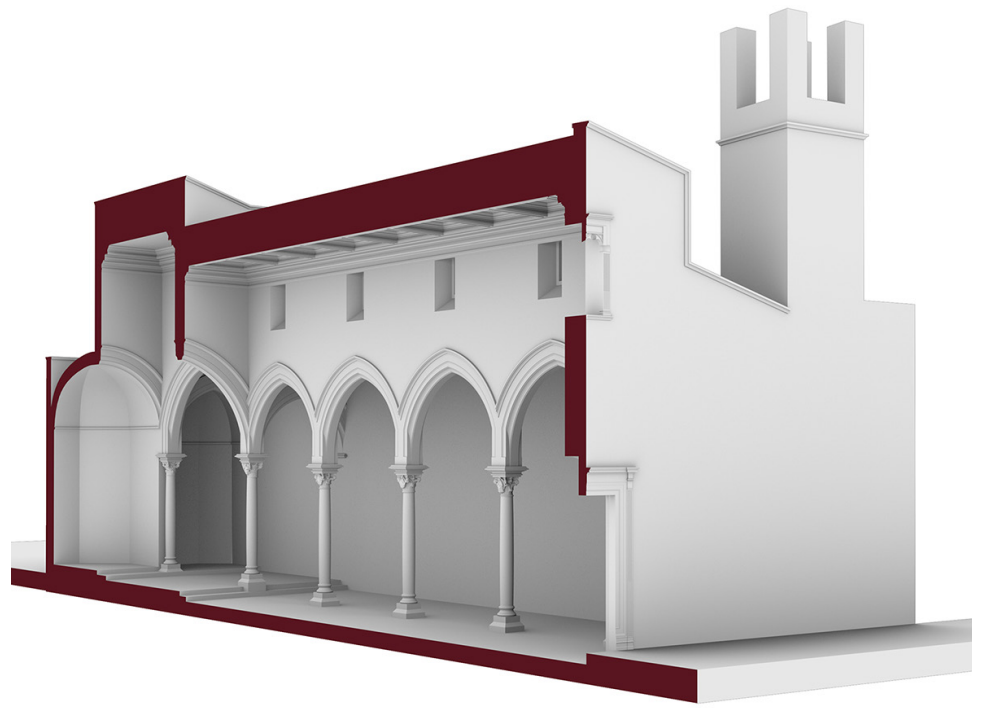

Questa soluzione consente una perfetta sovrapposizione tra i rendering del modello e i frame corrispondenti del video, ma spesso, come nel caso in esame, tale condizione non è sufficiente per ottenere un risultato ottimale. É frequente infatti, la presenza nella scena reale di oggetti posti su piani avanzati rispetto al modello virtuale; è il caso delle auto parcheggiate lungo la strada del nostro esempio, che verrebbero totalmente o parzialmente occultate dalla sovrapposizione dai frame relativi alla ricostruzione virtuale. Per tale ragione si è provveduto alla costruzione di modelli a basso numero di poligoni delle vetture presenti sul posto; questi modelli così creati, disposti virtualmente nello spazio 3D in corrispondenza di ciascuna auto, sono stati utilizzati come maschere 3D per occludere da ogni frame renderizzato la corrispondente porzione del modello ricostruttivo. L'utilizzo di un sistema di illuminazione virtuale congruo con le condizioni ambientali presenti durante la ripresa video e processi di correzione del colore hanno permesso di ottenere una perfetta simulazione del perduto spazio urbano (fig. I0).

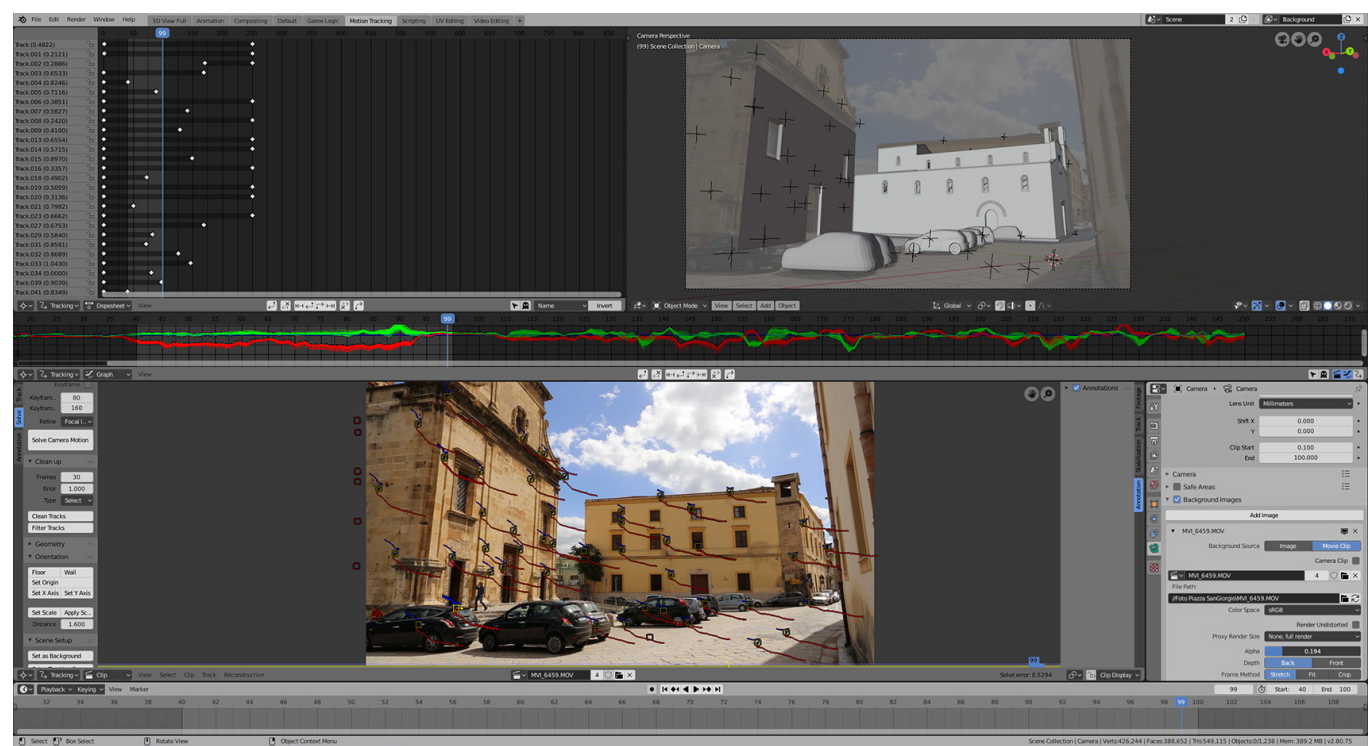




\section{Riconfigurazione congetturale (progetto Belguardo)}

La riconfigurazione congetturale dell'ipotetico progetto promosso dal magister Antonio Belguardo è stata elaborata sulla base del documento d'archivio e dell'analisi delle architetture realizzate dallo stesso. Come già anticipato, nel I526, il Belguardo venne incaricato di intagliare il materiale lapideo per la nuova riconfigurazione della chiesa dedicata all'Annunziata. Nei rilievi del 1933, l'architetto Pollaci rilevava dei pilastri a pianta ottagonale posti nella fabbrica attigua alla chiesa. Da un'analisi dimensionale essi risultano essere concordanti con le misure in palmi siciliani indicate nel documento, ed è pertanto plausibile ipotizzare infatti che questi, oramai realizzati, venissero impiegati per altri scopi.

Nel nuovo progetto sei campate, sormontate ciascuna da volte a crociera, avrebbero dovuto sostituire le cinque del precedente assetto. In particolare, in prossimità del presbiterio, nel punto in cui le ultime due arcate contrapposte presentano un interasse maggiore, appare plausibile l'inserimento di una volta a crociera a cinque chiavi, con un impianto planimetrico pressoché quadrato, secondo uno schema in tutto simile a quello adottato nella vicina chiesa di Santa Maria della Catena [Cannella, Giammusso 20 16, pp. 46-62], alla cui costruzione attese lo stesso Belguardo (figg. II, I2).

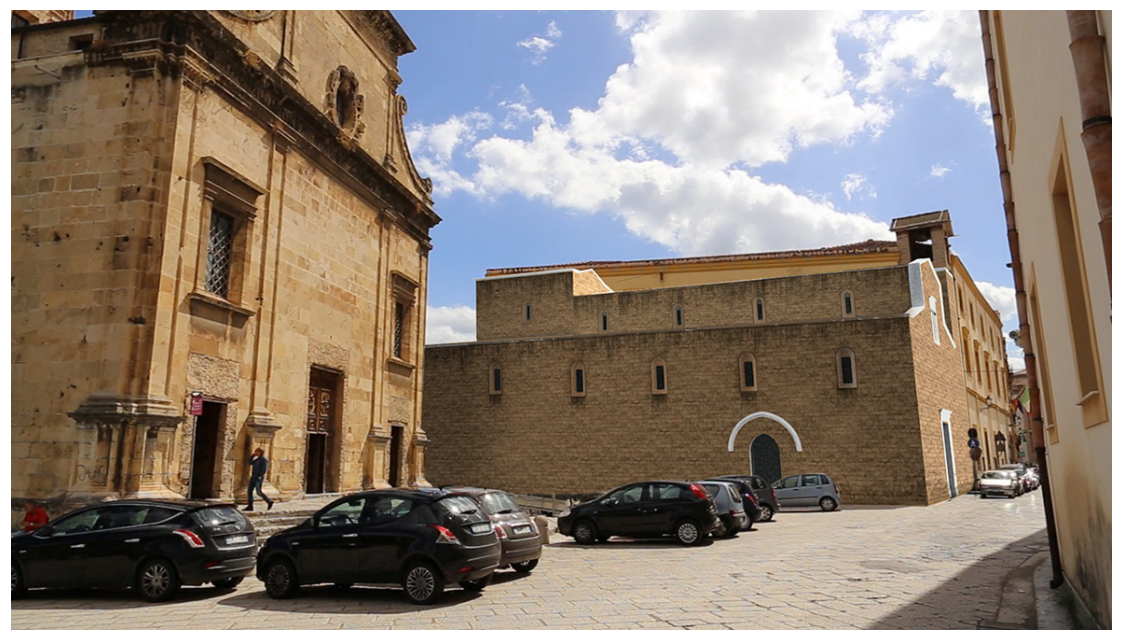

Fig. I I. Pianta congetturale dell'ipotetico progetto di Antonio Belguardo.

Fig. 12.Vista iposcopica dello spaccato assonometrico del modello congetturale 3D dell'ipotetico progetto di Antonio Belguardo. 


\section{Conclusioni}

Eventi bellici così come le calamità spesso oltre a provocare la perdita di vite umane, porta inevitabilmente anche la distruzione del prezioso patrimonio culturale, ne sono esempio la recente guerra civile siriana o il disastroso rogo che ha coinvolto la chiesa di Notre-Dame di Parigi. Lo studio presentato mostra come attraverso il rilievo, lo studio delle fonti documentali e l'ausilio delle tecniche di rappresentazione informatiche, è possibile restituire alla collettività, seppur in modo virtuale, brani di città o singoli edifici ormai perduti, strumento per il nutrimento della memoria culturale e di trasmissione verso le future generazioni.

\section{Note}

[I] Un palmo siciliano corrisponde a $25,775 \mathrm{~cm}$.

\section{Riferimenti bibliografici}

Garofalo Emanuela (20I5). Absidi poligonali e impianti basilicali della Sicilia tardomedievale. In Nobile Marco Rosario, Sutera Domenica (a cura di). L'abside costruzione e geometria. Palermo: Edizioni Caracol, p. 177.

Meli Filippo (1958). Matteo Carnilivari e l'architettura del Quattro e Cinquecento in Palermo. Roma: F.lli Palombi, pp. $104-108$.

Nobile Marco Rosario (2009). Chiese colonnari in Sicilia (XVI secolo). Palermo: Edizioni Caracol.

Pollaci Nino (1933). La chiesa dell'Annunciata a Porta S. Giorgio in Palermo. Palermo: Officine grafiche moderne Luxograph.

Savorra Massimiliano (2006). II medioevo e la Sicilia. Disegni e itinerari formativi dei Pensionnaires francesi nel XIX secolo. In Lexicon. Storie e architettura in Sicilia., n. 2, 2006, pp. 24-32.

Scaduto Fulvia (2007). Antonio Belguardo. In Garofalo Emanuela e Nobile Marco Rosario (a cura di). Gli ultimi indipendenti. Architetti del gotico nel Mediterraneo tra XV e XVI secolo. Palermo: Edizioni Caracol, pp. 190-191.

\section{Autore}

Mirco Cannella, Università degli Studi di Palermo, mirco.cannella@unipa.it

Per citare questo articolo: Cannella Mirco (2020). La perduta Chiesa dell'Annunziata presso Porta san Giorgio a Palermo: ipotesi e ricostruzioni virtuali. In Arena A., Arena M., Brandolino R.G., Colistra D., Ginex G., Mediati D., Nucifora S., Raffa P. (a cura di). Connettere. Un disegno per annodare e tessere. Atti del $42^{\circ}$ Convegno Internazionale dei Docenti delle Discipline della Rappresentazione/Connecting. Drawing for weaving relationships. Proceedings of the 42th International Conference of Representation Disciplines Teachers. Milano: FrancoAngeli, pp. $1842-1859$. 


\title{
The Lost Church of the Annunziata at Porta San Giorgio in Palermo: Hypotheses and Virtual Reconstructions
}

\author{
Mirco Cannella
}

Abstract

The Annunziata church was destroyed by the bombings of the Allies on May 91943 on the city of Palermo. However, important evidence remains of the church, built at the end of the I6th century and located near the San Giorgio gate: a 1832 drawing by Pierre-Joseph Garrez, preserved in Paris, at the Ecole nationale supérieure des Beaux-Arts, the survey of the architect Nino Pollaci of the early twentieth century, a series of historical photos, the surviving architectural fragments such as the capitals and the painted wooden coffered ceiling, preserved in various Palermitan museums, and above all the bell tower, still the only trace on the site of the now disappeared church of the Annunziata.

To these testimonies is added an archival document of 1526 in which a contract for the construction of 14 octagonal pylons, including the base and capitals that were to be used for the renovation of the church according to the indications of the architect Antonio Belguardo was stipulated. From this document arose the suggestive hypothesis of a project that was to distort the original layout of the church and which, for reasons unknown to us, was never implemented. The proposed study has a twofold objective: to rebuild the church to virtually reconstitute the lost urban space through the elaboration of some perspective views and 3D animations, and to re-propose, a conjectural model of the hypothetical project proposed by Belguardo for the renovation never implemented of the church.

Keywords

virtual reconstructions, Church of the Annunziata, Palermo, motion tracking, laser scanning.

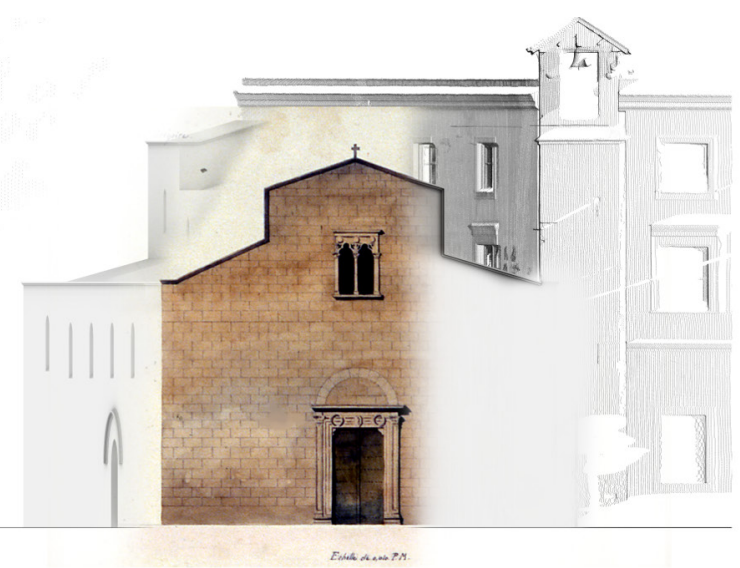

185 |

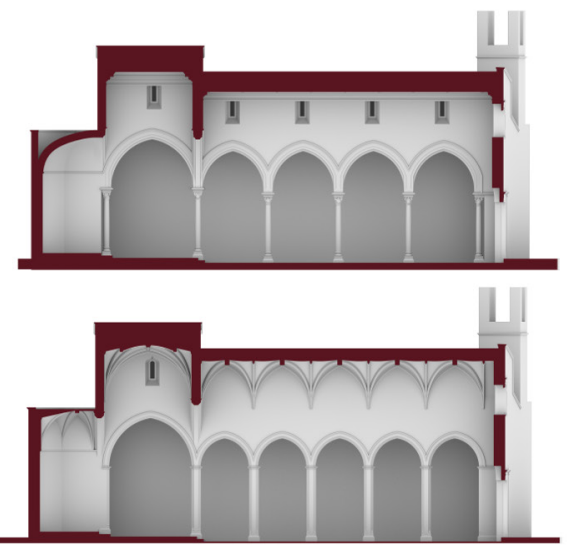

doi.org/| 0.3280/oa-548. 10 | 
Fig. I. Portion of the orthophoto of the city of Palermo with indication of the area occupied by the destroyed church of the Annunziata at Porta San Giorgio.

\section{Church of the Annunziata}

During the last world war, the city of Palermo was the first in Italy to experience the devastating effects of the carpet bombing by the Anglo-American Allies: after the last air raid, which took place on the night of May 9, 1943, much of the residential and monumental urban fabric of the city was now destroyed.

Among the buildings involved in the devastation is also the Annunziata Church which was completely razed to the ground. In the site where the church once stood, there is today a square, called San Giorgio dei Genovesi, named after the sixteenth-century church (still existing) built next to the Annunciation but in a position set back from the road front (fig. I). To testify the existence of the lost church remain the bell tower, visible on the right side of the square, and the building complex once attached to it (originally probably a convent, which became an orphanage in the following centuries and today houses the Conservatory of Music of Palermo "A. Scarlatti") (fig. 2).

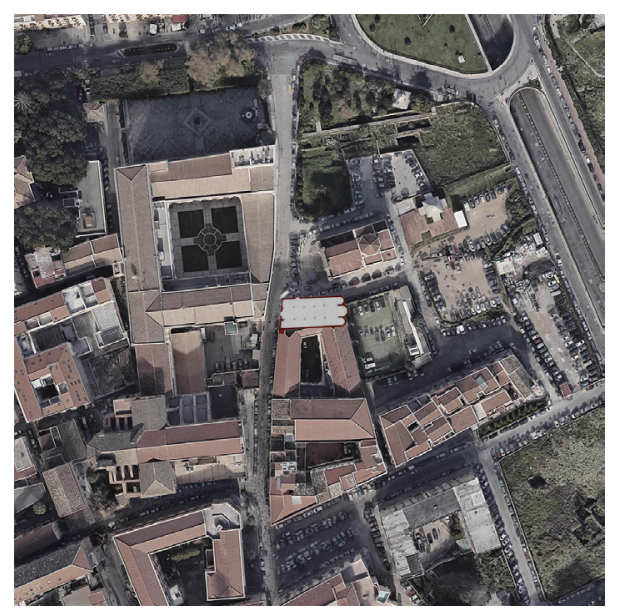

It is not easy to have a clear idea of the fourteenth-century layout of the church of the Annunziata. The lack of ancient evidence is associated with the fact that, at the end of the fifteenth century, it underwent an important restoration intervention by Gabriele di Battista from Como, magister builder active in those years in Palermo, who profoundly changed its appearance [Nobile 2009, pp. I3-15]. Of the original structure, the polygonal apses [Garofalo 20 I5, p. 177] were probably maintained, while, to separate the three naves, two rows of five columnar arches with a slightly pointed arch were inserted. The restoration also affected the exterior, with the remaking of the main façade in which, in particular, a bifora and a portal were built, made of white marble and richly sculpted by Domenico Gagini; himself made the twelve marble columns of the naves with their bases and capitals. The latter, as well as other precious architectural fragments, partly survived thanks to their recovery from the rubble in

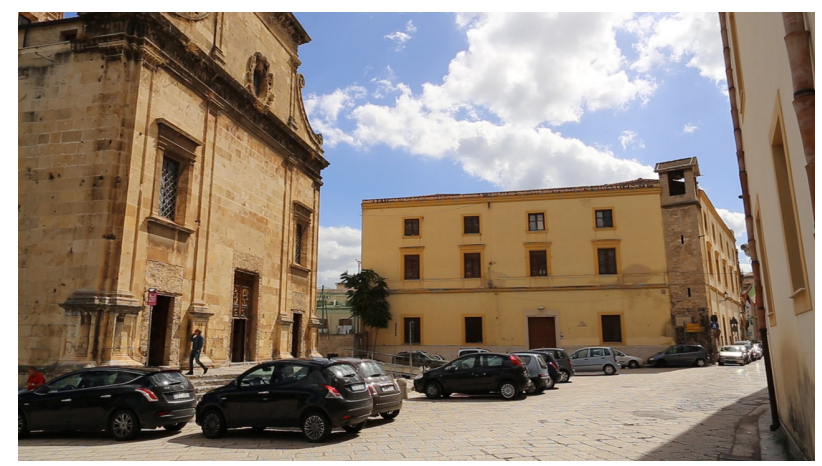


Fig. 3. P. J. Garrez, church of the Annunziata at Palermo, 1832 (École Nationale Supérieure des Beaux Arts, at Parigi).

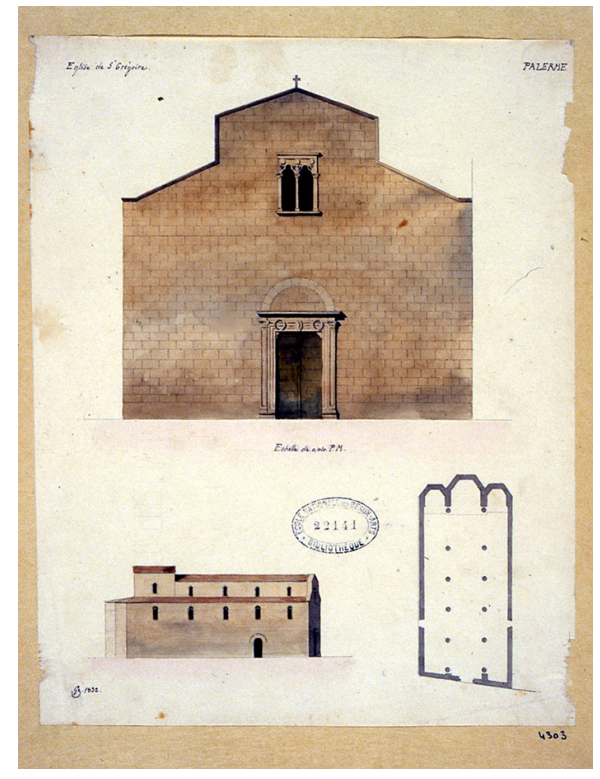

the aftermath of the disastrous bombing and are now preserved in the Regional Gallery of Sicily in Palazzo Abatellis in Palermo. The Diocesan Museum of the Archbishop's Palace in Palermo houses the large canvases that decorated the coffered ceiling of the central nave, painted by the Campanian artist Mario di Laurito (mid- I 6th century).

The first representation that has come down to us of the now lost church consists of a watercolor painting by the French architect Pierre Joseph Garrez (| 802- | 852) (fig. 3). As a student of the École des Beaux-Arts and winner of the Grand Prix in 1830, Garrez had had the opportunity to spend a period of training in Rome to devote himself to the study of classical architecture and to undertake trips to discover Italy aimed at to the analysis and survey of classical architecture on the basis of direct knowledge of monuments and archaeological sites.

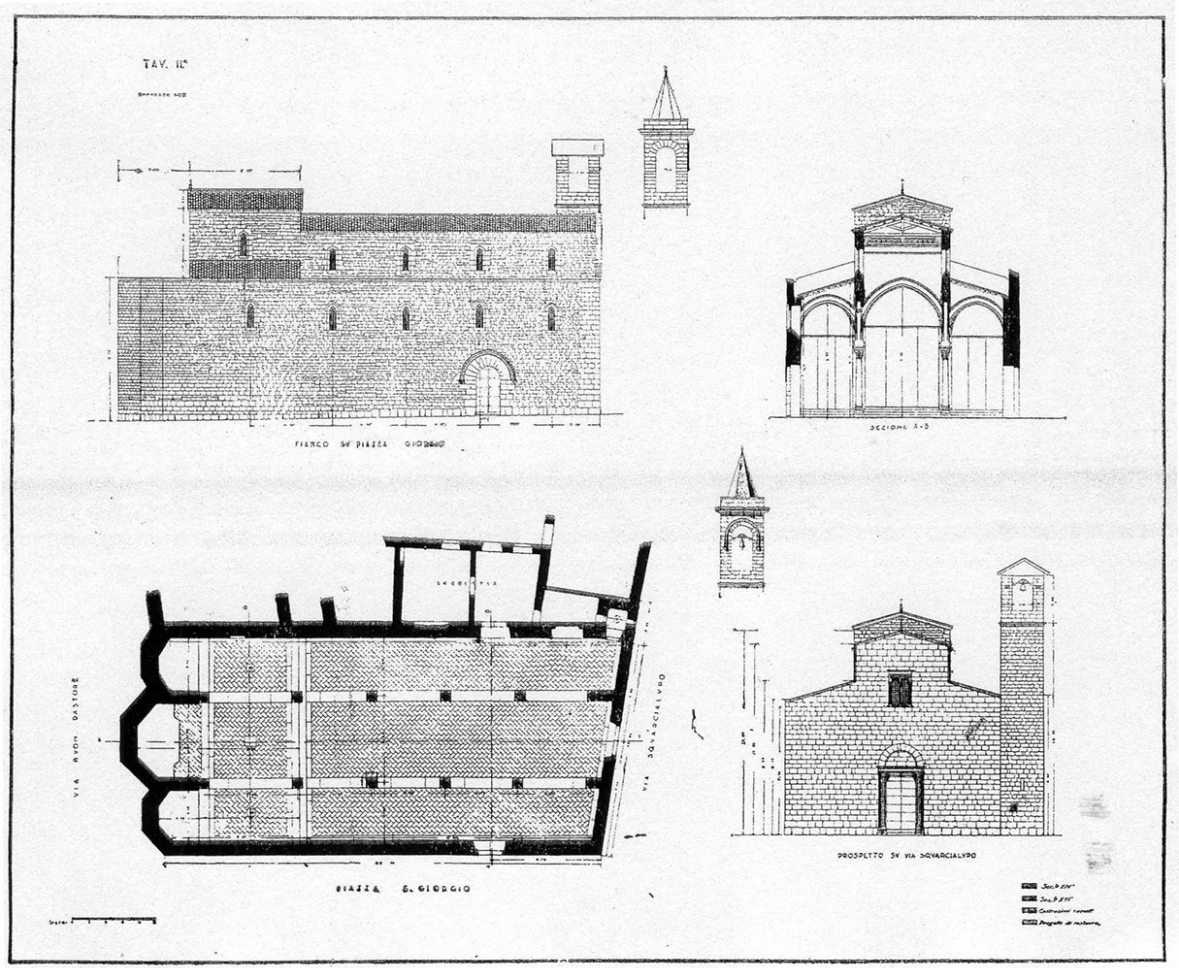


Fig. 5. Photos of the first half of the twentieth-century of the main front of the Annunziata church.
The interest of these students of the early nineteenth century often went beyond the exclusive study of classical sites: it is not unusual in fact to find among their numerous drawings also accurate surveys and meticulous drawings of medieval buildings [Savorra 2006, pp. 2432]. The itinerary of the young French architect/artist involved Sicily, where Garrez arrived in 1832: during his stay, he carried out the surveys and created a table, in pencil and watercolor, in which he represented, at different scales, the main elevation, the left lateral front and the plan of a church, erroneously named by him of San Gregorio. The drawing, now preserved at the Ecole Nationale Supérieure des Beaux-Arts in Paris, actually reproduces the church of the Annunziata, as has been observed by MR Nobile [Nobile 2009, pp. I 4], and as confirmed on the basis of comparison with some photographs of the early twentieth century and correspondences with the surveys made, in the same period, by the architect Nino Pollaci. Through the survey made by Pollaci, published in 1933 [Pollaci 1933] in ten tables, it is possible to clearly understand the architectural structure of the church (fig. 4). The drawings

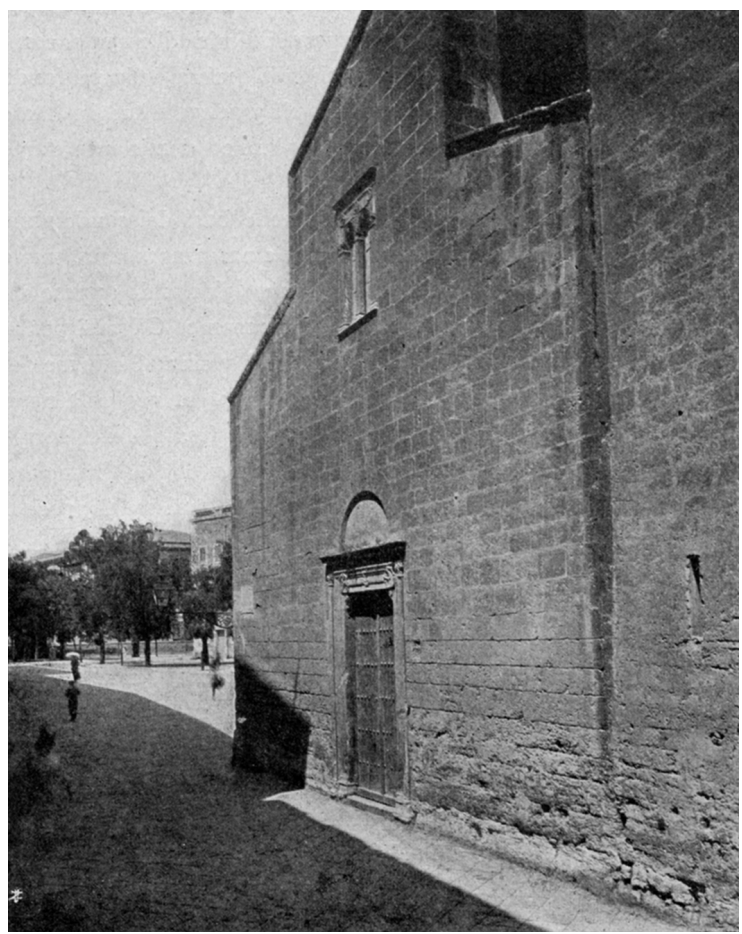

describe the overall structure of the building through a general plan, a plan, elevations, different sections, and an axonometric cross-section. Other tables are dedicated to architectural and decorative details such as the capitals, the portal, and the bifora already mentioned and the real profiles of the moldings of the arches of the naves as well as the pulvinus and the bases of the columns. From the drawings shows that the church was almost 30 meters long and 13.60 wide, while the upper part of the main front was no more than just over 12 meters; the bell tower, never completed, stopped at an altitude of 15.30 meters from the ground (fig. 5).

The recent discovery of a suggestive archival document has given a new impetus to the start of the study of this disappeared architecture: in the document, dated 1526 [Scaduto 2007, pp. 190, 191], "the rectors of the Church of the Annunziata in Porta San Giorgio" confer to the magister Antonio Belguardo the task of creating 14 octagonal section pillars, wide at least 2 Sicilian palms [I] and a quarter and high at least 18, to be used in the renovation of the church. This project was never completed, but some of the aforementioned pillars, already built, were still used in different parts of the building annexed to the church itself, as can be seen from the drawings dedicated to this building by Pollaci.

The study that is proposed here has a dual purpose: the first is focused on proposing a 
Fig. 6. Photogrammetric survey of one of the capitals made by

Domenico Gagini for the

Annunziata church, now exhibited in the sculpture room of the Regional Gallery of Sicily. virtual reconstruction of the church in the configuration before its destruction and substantially in the sixteenth-century version designed by Gabriele da Como. This model will be used to figure the original urban scenario in some photographic takes of the current state through image compositing techniques, and the production of a video animation using motion tracking techniques.

Furthermore, the hypothesis of a possible configuration of the project never carried out will be presented here, based on the analysis of the archive data and the comparison with some architectures created by Antonio Belguardo himself, engaged, in the same years, in other important buildings of the city of Palermo such as the church of Santa Maria della Catena and the most imposing church of Santa Maria dello Spasimo.
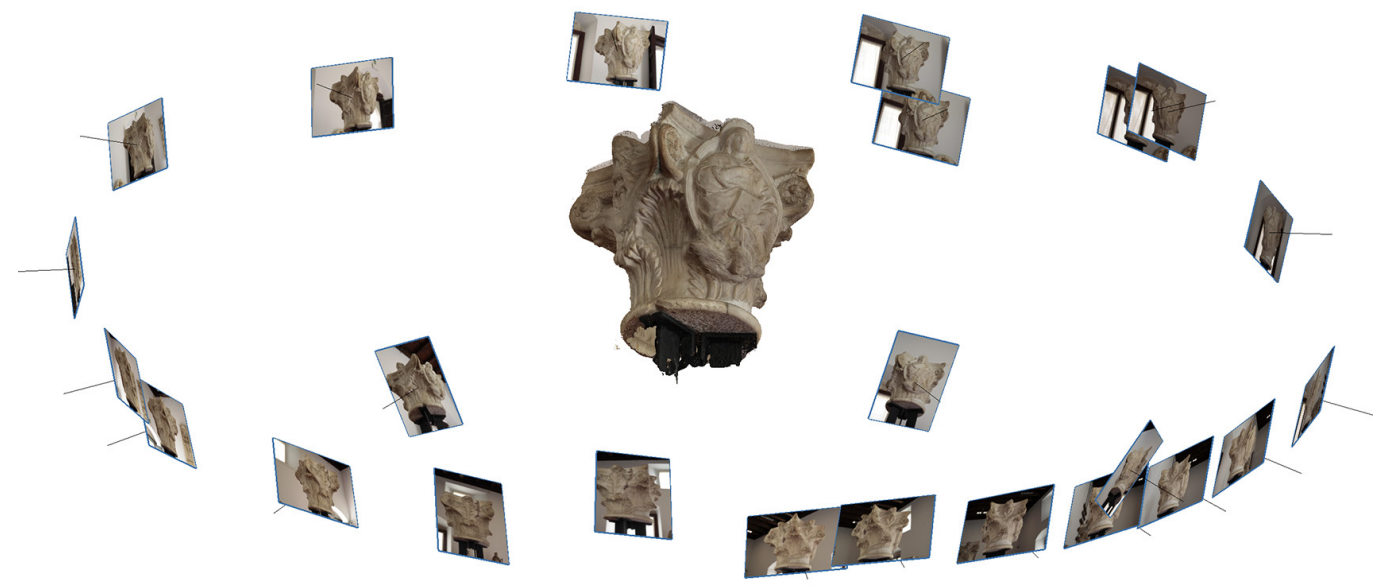

\section{Virtual reconstruction (Gabriele da Como project)}

The virtual reconstruction of the Annunziata church started from the integration between the metric data indicated by the architect Pollaci and the laser scanning information. A series of acquisitions have been made with laser scanners for documentation of the actual state and above all of the surviving bell tower, the only useful element for the dimensional verification of the twentieth-century drawings and for the correct virtual positioning of the church in the urban setting. At the same time, photographic shots were taken, aimed at developing a photogrammetric project, and video footage intended to produce animations with the virtual insertion of the church. The capitals and bases of the lost columns exhibited in the room dedicated to sculpture in the Museum of Palazzo Abatellis were also surveyed: each fragment was detected individually with photogrammetric methods in order to obtain 3D digital copies to be included in the virtual reconstruction of the church (fig. 6).

The digital reconstruction, processed with software CAD, began with the modeling of the bell tower based on laser scanning data (fig. 7). The integration of the data with the rich documentation of the twentieth-century surveys allowed a complete virtual reconstruction of the entire building in all its details, in its configuration before its destruction in the last century. 
The model, thus created, was used to produce some axonometric and perspective views. (fig. 8) Subsequently, it was further enriched with materials information, fundamental to document the reconfiguration intervention undergone by the church concerning its original fourteenth-century structure. Thanks to the studying of the blocks' size made through the twentieth-century surveys and especially through the historical photos, it was, in fact, possible to identify two different eras of realization: the lateral front and the apses have made with the use of small ashlars, following the construction techniques typical of the Sicilian Middle Ages, While the façade, as well as the cantonal one, were built with larger sandstone blocks, in line with the techniques used in the fifteenth century and perfectly compatible with the renovation mentioned above.

The surface treatment of the 3D model was carried out with textures elaborated through the sampling of photographic images of wall facings of buildings coeval with the two different construction phases. The model, thus textured, was used to simulate the original urban scenario through the creation of some photographic photomontages. The decision to impose a single reference system between the photogrammetric project and the 3D model has made it possible to recover all the position and direction parameters of the virtual cameras corresponding to the selected shots. The solution adopted facilitated the process of overlapping and merging the photographs and rendered views and, consequently, the editing of the final image.

A similar product but applied to a video sequence was created using the motion tracking technique, using the tools available in the 3D Blender modeling software (fig. 9). These allow you to calculate the path taken by the video camera and convert these displacements into 3D animation as well as solve the intrinsic parameters of the same as the focal length and lens distortion. This process takes place through semi-automatic analysis procedures and identification of homologous points on every single frame and the subsequent calculation of their spatial position. The introduction in the calculation process of known points traced on the frames manually, as in the case in question, facilitates the subsequent steps of scaling and definition of a unique reference system between the animation of the camera and the 3D models created. This solution allows a perfect overlap between the model renderings and the corresponding video frames. Still, often, as in the case in question, this condition is

Fig. 7. Laser scanning survey of the San Giorgio dei Genovesi square:

model of the Annunziata church.
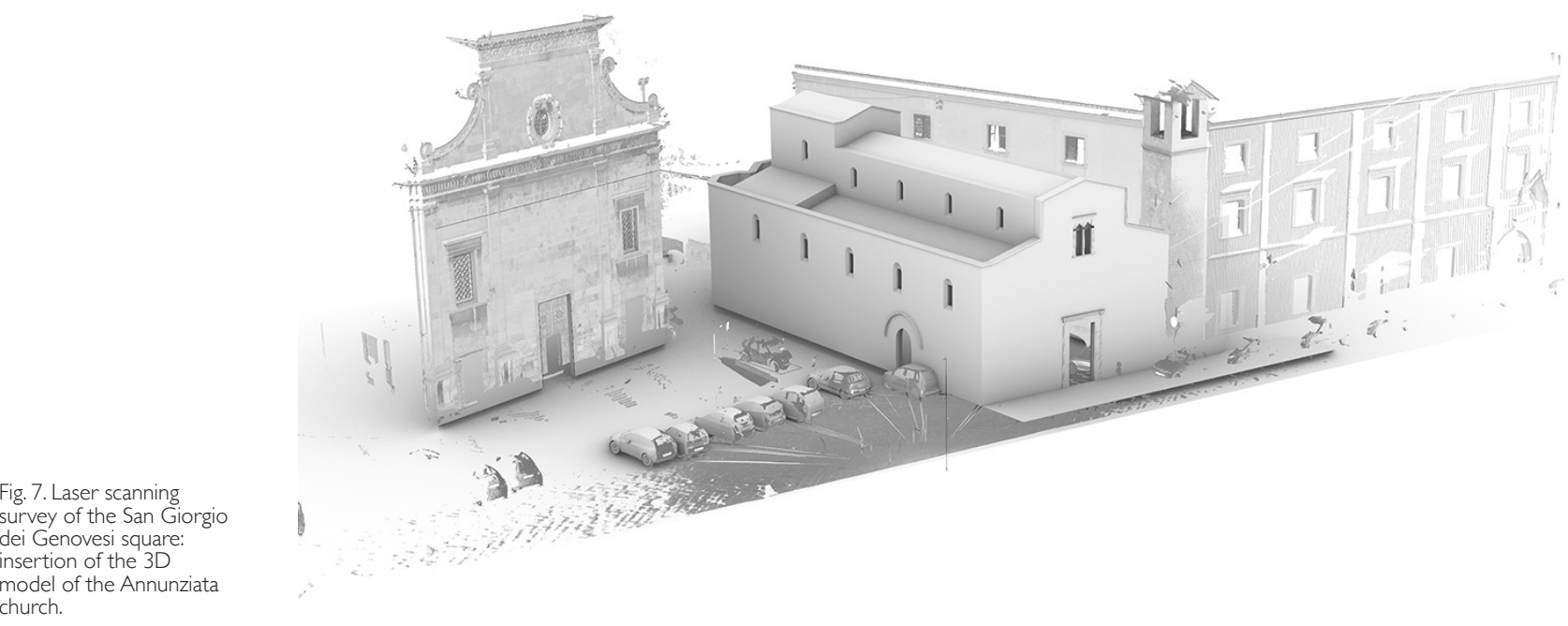
Fig. 8. Perspective crosssection of the virtual model of the Annunziata church as it appeared in 1943 .

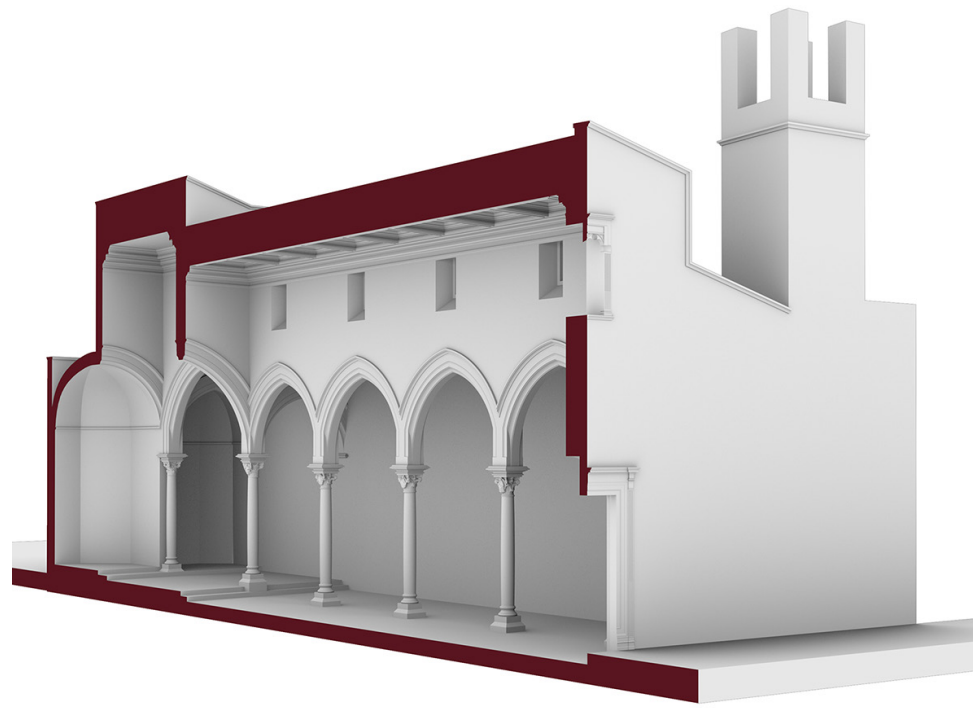

not sufficient to obtain an optimal result. The presence in the real scene of objects placed on an advanced plane to the virtual model is frequent, such as the cars parked along the road of our case, which would totally or partially be hidden by the frames related to the virtual construction. For this reason, low-polygon models of the cars present on site were built; these models thus created, virtually arranged in the 3D space at each car, were used as $3 \mathrm{D}$ masks to occlude the corresponding portion of the reconstructive model from each rendered frame.

The use of a virtual lighting system consistent with the environmental conditions presents during video shooting, and color correction processes have allowed us to obtain a perfect simulation of the lost urban space (fig. I0).

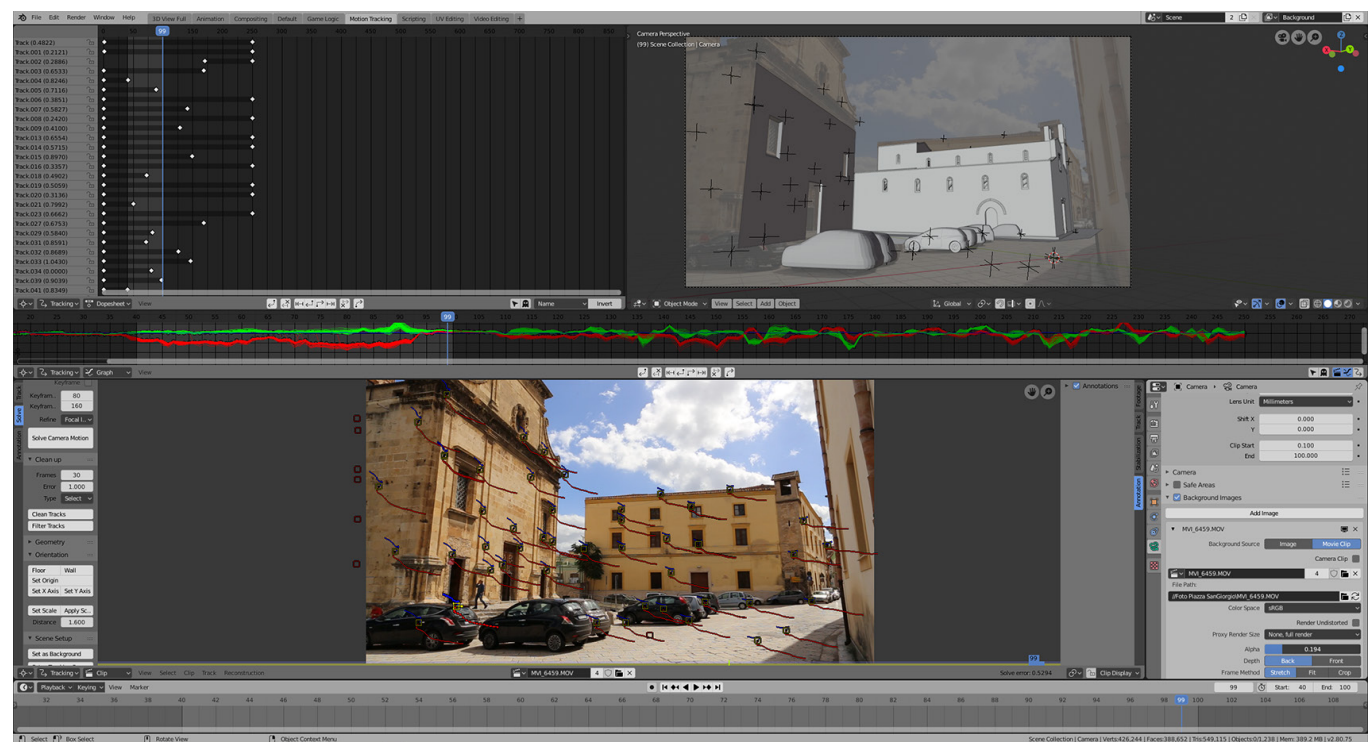




\section{Conjectural reconfiguration (Belguardo project)}

The conjectural reconfiguration of the hypothetical project promoted by the magister Antonio Belguardo, was elaborated based on the archive document and the analysis of the architectures created by the same.

As already mentioned, in 1526, Belguardo was commissioned to carve the stone material for the new reconfiguration of the church dedicated to the Annunciation. In the surveys of 1933, the architect Pollaci drawing the octagonal pillars placed in the adjoining building to the church. From dimensional analysis, they are consistent with the measurements in Sicilian palms indicated in the document, and it is, therefore, plausible to assume that these, now made, were used for other purposes.

In the new project, six spans, each surmounted by cross vaults, should have replaced the five of the previous structure. In particular, in the presbytery, where the last two opposing arches have a larger span, the insertion of a five-key cross vault, with an almost square planimetric layout, according to a scheme similar to the one adopted in the nearby church of Santa Maria della Catena [Cannella, Giammusso 20 I6, pp. 46-62], the construction of which Belguardo expected (figs. II, I2).

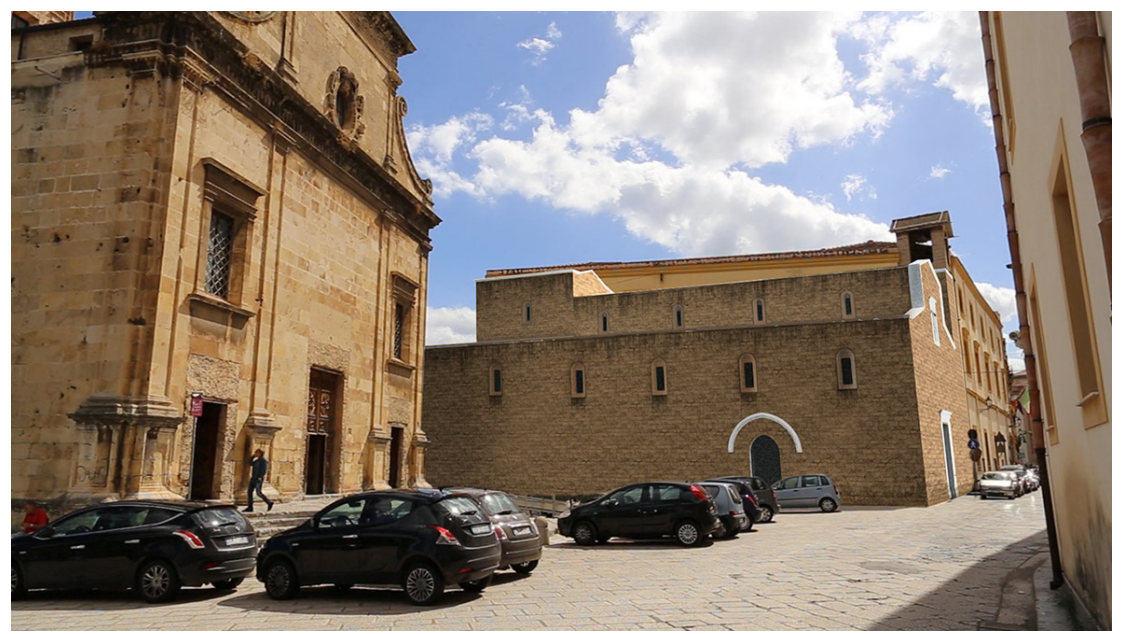

Fig. I I. Conjectural plan of the hypothetical project by Antonio Belguardo.

Fig. 12. Hyposcopic view of the axonometric cross-section of the 3D conjectural model of the hypothetical project by hypothetical project
Antonio Belguardo. 


\section{Conclusions}

War events as well as calamities often in addition to causing the loss of human lives, inevitably also lead to the destruction of the precious cultural heritage, are an example of the recent Syrian civil war or the disastrous stake that involved the Notre-Dame de Paris church. The study presented shows that through the survey, the study of documentary sources and the aid of computer representation techniques, it is possible to return to the community, albeit virtually, pieces of cities or individual buildings now lost, an instrument for nourishing memory cultural and the transmission towards future generations.

\section{Notes}

[I] A Sicilian palm corresponds to $25.775 \mathrm{~cm}$.

\section{References}

Garofalo Emanuela (20I5). Absidi poligonali e impianti basilicali della Sicilia tardomedievale. In Nobile Marco Rosario, Sutera Domenica (a cura di). L'abside costruzione e geometria. Palermo: Edizioni Caracol, p. 177.

Meli Filippo (1958). Matteo Carnilivari e l'architettura del Quattro e Cinquecento in Palermo. Roma: F.lli Palombi, pp. $104-108$.

Nobile Marco Rosario (2009). Chiese colonnari in Sicilia (XVI secolo). Palermo: Edizioni Caracol.

Pollaci Nino (1933). La chiesa dell'Annunciata a Porta S. Giorgio in Palermo. Palermo: Officine grafiche moderne Luxograph.

Savorra Massimiliano (2006). II medioevo e la Sicilia. Disegni e itinerari formativi dei Pensionnaires francesi nel XIX secolo. In Lexicon. Storie e architettura in Sicilia., n. 2, 2006, pp. 24-32.

Scaduto Fulvia (2007). Antonio Belguardo. In Garofalo Emanuela e Nobile Marco Rosario (a cura di). Gli ultimi indipendenti. Architetti del gotico nel Mediterraneo tra XV e XVI secolo. Palermo: Edizioni Caracol, pp. 190-191.

\section{Author}

Mirco Cannella, Università degli Studi di Palermo, mirco.cannella@unipa.it

To cite this chapter. Cannella Mirco (2020). La perduta Chiesa dell'Annunziata presso Porta san Giorgio a Palermo: ipotesi e ricostruzioni virtuali. In Arena A., Arena M., Brandolino R.G., Colistra D., Ginex G., Mediati D., Nucifora S., Raffa P. (a cura di). Connettere. Un disegno per annodare e tessere. Atti del $42^{\circ}$ Convegno Internazionale dei Docenti delle Discipline della Rappresentazione/ Connecting. Drawing for weaving relationships. Proceedings of the 42th International Conference of Representation Disciplines Teachers. Milano: FrancoAngeli, pp. $1842-1859$. 